University of Wollongong

Research Online

Faculty of Business - Papers (Archive)

Faculty of Business and Law

$1-1-2015$

Toxic products and hazardous waste: The global asbestos issue

Lee C. Moerman

University of Wollongong, leem@uow.edu.au

Sandra van der Laan

University of Sydney, s.vanderlaan@econ.usyd.edu.au

Follow this and additional works at: https://ro.uow.edu.au/buspapers

Part of the Business Commons

Research Online is the open access institutional repository for the University of Wollongong. For further information contact the UOW Library: research-pubs@uow.edu.au 


\title{
Toxic products and hazardous waste: The global asbestos issue
}

\author{
Abstract \\ This chapter considers the toxic chemical asbestos as a salient example of the ever-widening gap in \\ achieving the paradoxical aspirations of ensuring a high-quality environment and a healthy economy \\ espoused in the Agenda 21 principles arising from the Earth Summit in 1992. In particular, this chapter \\ reviews the scrutiny proposed around the production of toxic components and the disposal of poisonous \\ and hazardous wastes. Despite an increase in global regulation, the elimination of asbestos mining, \\ production and disposal of waste has not been achieved globally. We consider the various non- \\ government and supranational organisations that provide commentary and responses to the global \\ asbestos issue, as well as, a sample of key campaigns and corporate exemplars to highlight issues of \\ governance and risk. \\ Keywords \\ products, hazardous, waste, global, toxic, asbestos, issue \\ Disciplines \\ Business \\ Publication Details \\ Moerman, L. \& van der Laan, S. (2015). Toxic products and hazardous waste: The global asbestos issue. \\ In D. Dr D Crowther \& M. Azizul. Islam (Eds.), Sustainability after Rio (pp. 103-120). Bingley, UK: Emerald \\ Group Publishing Limited.
}




\title{
CHAPTER X
}

\section{TOXIC PRODUCTS \& HAZARDOUS WASTE:}

\author{
THE GLOBAL ASBESTOS ISSUE
}

\section{Lee Moerman and Sandra van der Laan}

\begin{abstract}
This chapter considers the toxic chemical asbestos as a salient example of the ever-widening gap in achieving the paradoxical aspirations of ensuring a high quality environment and a healthy economy espoused in the Agenda 21 principles arising from the Earth Summit in 1992. In particular, this chapter reviews the scrutiny proposed around the production of toxic components and the disposal of poisonous and hazardous wastes. Despite an increase in global regulation, the elimination of asbestos mining, production and disposal of waste has not been achieved globally. We consider the various non-government and supranational organisations which provide commentary and responses the global asbestos issue as well as a sample of key campaigns and corporate exemplars to highlight issues of governance and risk.
\end{abstract}

\section{INTRODUCTION}

A comprehensive blueprint for a global partnership, Agenda 21 strives to reconcile the twin requirements of a high quality environment and a healthy economy for all people of the world... (UNESCO, n.d., p.1)

In 1992, the participants of the Earth Summit ${ }^{1}$ in Rio de Janeiro proposed the ideal of a world where the environment and the economy could co-exist in a manner that promoted sustainably for both. More than two decades later, global concerns, such as poverty, climate change and unstable financial markets indicate a widening poverty gap, an increasing incidence of climate events and financial crises. Within this context, we reflect on Agenda 21 as a product of the Earth Summit that established a plan of action to embed sustainability in all areas $21^{\text {st }}$ century development. In particular, we address the proposed scrutiny of the production of toxic components and the disposal of poisonous and hazardous wastes (Chapters 19 and 20 of Agenda 21 respectively). The Earth Summit envisioned a holistic approach to global issues affecting the environment and development by building on the localised and fragmented efforts of nations, organisations, governments and individuals. This chapter explores the various global mechanisms, Non-Government-Organisations (NGOs), multilateral agreements, and supranational organisations that attempt to ameliorate the exploitation and proliferation of asbestos. Since sustainability encompasses business and the economy, we also consider the responses of industry to the risks from corporate involvement with a toxic chemical to draw out implications for corporate governance in a new era of sustainability and development twenty years on from Rio. In the past, this has included elaborate corporate restructures to leverage bankruptcy or insolvency regimes in an effort to 
avoid the financial uncertainty from the long-tail liability that arises from asbestos-related disease.

Asbestos is a naturally-occurring mineral exploited industrially for its inherent and desirable qualities of heat resistance, flexibility and strength. Paradoxically, while providing a cheap and durable material for domestic and commercial use, asbestos is toxic to humans. While many manufactured products also contain poisonous and hazardous substances; the continued mining and use of asbestos, coupled with the toxic legacy of asbestos-containing material (ACM) in the environment, is a primary example of the frustrated ambitions of the architects of the "blueprint for a global partnership" (UNESCO, n.d., p.1). In the context of proliferating international and national corporate governance regimes and corporate risk management strategies, the global asbestos industry provides a salient example of the tension between the responsibilities for current and future generations and a sustainable business environment.

Historically, the mining and manufacture of asbestos largely occurred in industrialised nations such as Australia, the UK, the US, Canada ${ }^{2}$, Belgium, Italy as well as less-developed countries such as South Africa and Zimbabwe from the early 20th century through to the 1980s. While asbestos is now banned in most developed nations, its use is still significant worldwide despite almost a century of known industrial occupational health effects and six decades of incontrovertible evidence of the risks from incidental or environmental exposure. As recently as 2013, there was an estimated global production of 2 million tonnes (Virta 2014) indicating that asbestos use is on the rise worldwide, with over half of the total consumption occurring in China and India (Virta 2013). This is not surprising since in developed countries, such as Australia, the United States (US) and the United Kingdom (UK) asbestos has been banned recently. While there are several reasons, these national responses arise from several factors including; increased knowledge of the risks of exposure to asbestos, sophisticated legal environments with the availability of strategic options and technological capacity to invest in substitutes.

The World Health Organization (WHO) provides alarming statistics about this global disaster. As at 2010, approximately 125 million people were still being exposed to asbestos in the workplace with an estimated $50 \%$ of workplace deaths occurring from asbestos-related cancers (WHO 2010). Therefore, there are considerable implications for the achievement of a high quality environment for workers, their families, the general public and future generations. In terms of economic or business sustainability, the problem of company 'insolvency' is a major one and has been a factor in the response to asbestos issues (ILO 2014). The next section provides a background of the social and health related risks, followed by a discussion of the various global regimes regulating asbestos. Various non-government and supranational organisations provide commentary and responses to the global asbestos issue and a sample of key campaigns preface a discussion and examples of corporate governance and risk in light of the Earth Summit's aspirations to scrutinise the patterns of production of toxic components and the disposal of poisonous waste (UNCED 1992). 


\section{THE TOXIC PRODUCT \& HAZARDOUS WASTE}

The improvement of human health is one of the most important objectives of development. The deterioration of environmental quality, notably air, water and soil pollution owing to toxic chemicals, hazardous wastes, radiation and other sources, is a matter of growing concern (Agenda 21 16.11)

Agenda 21 emerged from the Earth Summit as a set of principles and guidelines to operationalise the sentiments arising from the Rio Declaration on the Environment and Development (1992). In particular, Chapters 19 and 20 of Agenda 21 address Environmentally Sound Management of Toxic Chemicals, Including Prevention of Illegal International Traffic in Toxic and Dangerous Products and Environmentally Sound Management of Hazardous Wastes, Including Prevention of Illegal International Traffic in Hazardous Wastes respectively.

Chapter 19 of Agenda 21 (19.1) noted that a "substantial use of chemicals is essential to meet the social and economic goals of the world" and "that they can be used widely in a costeffective manner and with a high degree of safety". Six programme areas were proposed to coalesce with the principles of sustainable development and improved quality of life

There is international concern that part of the international movement of toxic and dangerous products is being carried out in contravention of existing national legislation and international instruments, to the detriment of the environment and public health of all countries, particularly developing countries (Agenda 21 19.9) including: assessment of chemical risks; classification and labelling issues; information exchange; risk reduction programmes; local management programmes and prevention of illegal international traffic (Agenda 21, 19.4). It was acknowledged that these objectives could only be achieved with support and cooperation of governments, international organisations and industry. It was also proposed that policies be developed and implemented around producer liability principles and life-cycle approaches to chemical management that cover manufacturing, trade, transport, use and disposal. Additionally, policies should be adopted to phase out chemicals that pose unreasonable and unmanageable risks to human health and the environment (Agenda 21 19.49).

Chapter 20 focuses on the effective control of the generation, storage, treatment, recycling and reuse, transport, recovery and disposal of hazardous wastes to promote health, environmental protection and sustainable development. Again achievement of this objective requires multi-partisan support from the international community, governments and industry. Specifically identified was the important role that "large industrial enterprises including transnational corporations and domestic industry" (Agenda 2120.1 ) have in preventing illegal activities and the management of hazardous waste. It is from within the context of Agenda 21 that we review efforts at management and control of the known carcinogenic chemical, asbestos. 


\begin{abstract}
ASBESTOS
The term asbestos comes from the Ancient Greek and means 'inextinguishable' or 'unquenchable' (Salvatore et al. 2003, p. 2). The chemical belongs to a family of fibrous silicates and is used in a diverse range of manufactured products that require heat and acid resistant qualities such as brake linings, building materials and insulation. Chrysotile or white asbestos accounts for the majority of use, although amosite or brown asbestos and crocidolite or blue asbestos have also been commercially exploited to varying degrees (Moerman and van der Laan 2013). While the toxicity of these different types of asbestos is debated (Lee 2005), evidence has shown that all types of asbestos are carcinogenic (IARC Monograph Working Group 2009).

The health-related risks of exposure to asbestos have been documented since at least the $1^{\text {st }}$ century AD (Lowe 2004), however it was not until several landmark scientific studies in the late 1950s through to the early 1960s that a definitive link was established with asbestosis, lung cancer and mesothelioma. Exposure to asbestos can result in a range of known effects, from asymptomatic scarring of the lungs (pleural plaques) to functionally-limiting disease. Pneumoconiosis or workers' lung disease (asbestosis) is generally related to the quantum of exposure and inhalation

Asia is the centre of the
"asbestos epidemic" and
campaigns focussing on
workers' rights and safety
often target these emerging
economies (APHEDA, 2013,
p.1) For example, Union Aid
Abroad (APHEDA) is the
overseas humanitarian aid
agency of the Australian
Council of Trade Unions
(ACTU) and advocates on
behalf of workers primarily in
the Pacific, South East Asia,
the Middle East and southern
Africa Currently, the campaign
centred on Laos highlights the
dangers of the 5 o00 tons of
asbestos imported from
Russia, China and Thailand for
the manufacture of roof tiles
(APHEDA 2013).
\end{abstract}
of industrial fibres from dust. On the other hand, the fatal and progressive asbestos-related cancer ${ }^{3}$, mesothelioma, can manifest from only tangential or incidental exposure and affects both workers and the general population, often decades later. Therefore, coordinated effects to: eliminate the use and trade of asbestos; substitute with a safer product; assist with technology; provide education and information; and, implement innovative treatments for asbestos-related disease are a high priority for legislators, regulators, workers' and health and safety organisations as well as disease and environmental lobbyists worldwide.

In 2003 the total production of asbestos was estimated at 2.1 million tons (around half of the peak global consumption in 1980 of 4.8 million tons) (Virta 2006). The production of asbestos over the last decade has remained relatively constant at 2 million tons (Virta 2013), however, the geographic spread has altered as Table 1 indicates. For example, Canada's production ceased in 2012 due to increased costs of production and the lack of political support for expansions to operations (Kazan-Allen 2013a). 
Table 1: 2012 Asbestos Trade Data*

Top five producers (tons) 2003

Russia
Kazakhstan
China
Canada
Brazil
Top five users (tons) 2003
China
Russia
India
Kazakhstan
Ukraine
* Virta (2006)
** http://www.ibasecretariat.org/

Top five producers (tons) 2012**

\begin{tabular}{llr}
878,000 & Russia & $1,000,000$ \\
354,500 & China & 420,000 \\
350,000 & Brazil & 306,500 \\
194,350 & Kazakhstan & 241,200 \\
194,350 & India & 20,000 \\
& Top five users (tons) 2012 \\
\hline 491,954 & China & 530,834 \\
429,020 & India & 493,086 \\
192,033 & Brazil & 167,602 \\
173,891 & Indonesia & 161,824 \\
156,393 & Russia & 155,476
\end{tabular}

The risks associated with asbestos cut across several domains including public health, workers' rights, safety and environmental contamination as well as governance and responsibility. Therefore, international and supranational organisations often propose a coordinated response to the global threat of asbestos. The following sections provide an overview of some of these initiatives consistent with the broad ideals of Agenda 21.

\section{GLOBAL REGULATION}

A major challenge to the systematic regulation of asbestos is the variety of legal and regulatory contexts in which asbestos has been, and continues to be, exploited. Each jurisdiction has unique arrangements for the regulation of asbestos. Additionally, it provides opportunities for entities operating in the industry to engage in 'forum shopping' and possibly 'jurisdictional arbitrage' in order to obviate the requirements of emerging regulation to combat the risks to public health. This lack of consistency and comparability threatens the realisation of the objectives of Agenda 21. Specifically, Principle 6 considers efforts to protect and promote human health since health and development are inextricably entwined. Global regulatory arrangements take the form of international environmental treaties (or

Prevention of the generation of hazardous wastes and the rehabilitation of contaminated sites are the key elements, and both require knowledge, experienced people, facilities, financial resources and technical and scientific capacities (Agenda 21 20.2) conventions) where signatories, generally sovereign states, assume obligations under international law and incorporate these into domestic legislation.

\section{The Rotterdam Convention}

The Rotterdam Convention on the Prior Informed Consent Procedure for Certain Hazardous Chemicals and Pesticides in International Trade (Rotterdam Convention) was promulgated in 1998 by the Conference of Plenipotentiaries. It entered into force on 24th February 2004 and created legally binding obligations for procedures governing the trade of pesticides and 
industrial chemicals that have been banned or severely restricted for health or environmental reasons (PIC 2008).

The Rotterdam Convention was developed by the United Nations Environment Program (UNEP) and the Food and Agriculture Organization (FAO) with the objective of:

Promot[ing] shared responsibility and cooperative efforts among Parties in the international trade of certain hazardous chemicals in order to protect human health and the environment from potential harm and to contribute to their environmentally sound use, by facilitating information exchange about their characteristics, by providing for a national decision-making process on their import and export and by disseminating these decisions to Parties (Rotterdam Convention, 2014).

While the Convention does not ban the trade in toxic substances per se it enforces procedures of consent prior to the importation of prescribed substances to limit their use. Some 40 substances are specified under the Rotterdam Convention and, while most types of asbestos are included, the most common asbestos exploited industrially, chrysotile (white asbestos), is omitted from the list. Indeed the specification of chrysotile has been hotly contested and the blocking of its inclusion at the most recent conference held in Geneva in 2013 is regarded as surrender of the objectives of the Convention to powerful economic interests (Kazan-Allen, 2013b).

\section{Basel Convention}

The proliferation of environmental regulation throughout the 1980s resulted in an increase of the cost of disposal of hazardous wastes and consequently led to the rise of a toxic waste industry. Two dimensions of this industry are of particular concern. First, transfers of transboundary toxic waste are received by less developed countries desperate for foreign currency. Second, "toxic traders", largely operating out of developing countries and Eastern Europe, transporting hazardous waste worldwide with relative impunity. These practices created international outrage and prompted and international response with the development of the Basel Convention on the Control of Transboundary Movements of Hazardous Wastes and Their Disposal (Basel Convention) in 1989 under the

India, Pakistan and Bangladesh are the three main shipbreaking destinations. Asian Ban Asbestos Network lobbies for end-of-life vessels to provide an inventory of hazardous materials to facilitate a safe work environment (NGO Shipbreaking Platform 2013) auspices of UNEP (Basel Secretariat 2011).

The objective of the Basel Convention is to protect human health and the environment by controls over the generation, storage, transport, reuse, recycling, recovery and disposal of hazardous waste (Basel Convention, 2014). Any waste containing asbestos falls under this convention. More recently, intervention over the management of hazardous chemicals and waste has escalated with more rigorous protocols and the synergies achieved from the cooperation of various conventions ${ }^{4}$. 


\section{SUPRANATIONAL AND INTERNATIONAL RESPONSES}

In addition to global regulation in the form of conventions and protocols, several supranational, civil society and NGOs contribute to efforts to limit the effects of asbestos. Given that asbestos cuts across issues of general health and morbidity, occupational health and safety and environmental degradation many of the initiatives represent a collective response incorporating several agencies. The following section highlights these domains of interest with reference to the Agenda 21 objective of preventing hazardous wastes and the generational effects of environmental contamination.

\section{World Health Organization (WHO)}

Asbestos is rated by WHO as one of the 10 chemicals (or groups of chemicals) of major public concern (WHO, 2010) and is considered a largely avoidable or controllable carcinogen. As previously noted, it is estimated that around 125 million people are exposed to asbestos in the workplace resulting in approximately 107,000 deaths/year and 1,523,000 DALYs 5 . More importantly, asbestos accounts for half of all deaths as a result of occupational cancer (WHO, 2010).

WHO aims to eliminate asbestos-related disease through the following measures:

- stop the use of all types of asbestos;

- replace asbestos with safer substitutes and develop mechanisms to stimulate replacement;

- take measures to prevent exposure to asbestos in situ and during removal (abatement), and;

- improve early diagnosis and treatment of asbestos-related diseases and establish a registry of people with past and/or current exposures to asbestos (WHO, 2010).

Principle 27: Strengthening the role of non-governmental organizations: partners for sustainable development in Agenda 21 specifically encourages the involvement of NGOs in policy development and decision-making. For example, to further the WHO objectives a joint project with the International Labour Organization (ILO) and UNEP was developed - the World Health Organization International Programme on Chemical Safety. The objectives of this programme are: to prevent the risk of exposure to asbestos dust at work; to prevent harmful effects on the health of workers arising from exposure to asbestos dust; and, to provide reasonably practicable control procedures and practices for minimising occupational exposure to asbestos dust (ILO, 2014).

\section{International Labour Organisation (ILO)}

The ILO objective of promoting internationally-recognised labour rights to encourage labour peace as an essential component of prosperity reflects the vision of the Earth Summit and the principles of Agenda 21 (ILO, 2014). Principle 29: Strengthening the role of workers and their trade unions in Agenda 21 challenges governments and industry to achieve sustainable employment for all in a safe, clean and healthy workplace through engagement with workers and trade unions. The focus on international policies and labour standards, as well as, 
cooperation with national labour groups provides examples of the promotion of decent work globally. While ILO Asbestos Convention, 1986 (No. 162), specifically prohibits all use of crocidolite (blue); chrysotile (white), on the other hand, is still extensively used in asbestos cement building materials in less developed countries. Unfortunately, the ILO's reluctance to ban chrysotile has been used as a defence by the industry to justify the continued use of asbestos.

Additionally, the ILO Occupational Cancer Convention, 1974 (No. 139) is an instrument designed to ensure that nations adopt appropriate measures to control and prevent occupational hazards caused by carcinogenic substances. For example, where asbestos is used, exposure levels are prescribed and monitored and, where possible, a non-carcinogenic material is substituted. In 2006, the ILO released a Resolution on Asbestos, reinforcing in the preamble that the ILO is:

[d]eeply concerned that workers continue to face serious risks from asbestos exposure, particularly in asbestos removal, demolition, building maintenance, ship-breaking and waste handling activities (ILO, 2006).

South Africa

The last mine operated by T\&N ceased operation in South Africa only in 2001 two years after all asbestos was banned in the UK. UK companies and insurers face an emerging legacy from the poverty and isolation of the mining regions, the ruthlessness of the employers, and the quiescence of the regulatory authorities [that] allowed British companies and their subsidiaries to enforce work conditions that would be unthinkable in an OECD state (McCulloch 2003).

Most notably the ILO is concerned about the construction industry, as the workforce is large and exposure is difficult to control in non-confined spaces. For example, after many years of lobbying in 2014, the Building and Woodworkers International (BWI) International Asbestos Conference in Vienna issued the Vienna Declaration. National construction trade union representatives, together with the International Union of Building and Wood Workers (UITBB) and other international labour organisations, declared to promote the implementation of:

the global ban of all forms of asbestos from the construction industry and from all other industrial sectors; to promote the effective regulation of work with in -situ asbestos in demolition, conversion, renovation and maintenance works by law; to work for the elimination of diseases caused by asbestos; to promote social justice for those affected by asbestos (BWI, 2014).

In addition to specific labour lobby groups, civil society organisations also support the ban of asbestos as both an occupational and environmental hazard. For example the Ban Asbestos Network is an umbrella organisation that promotes regional and national projects. In particular, the Bangladesh Ban Asbestos Network was established to lobby for regulation in the shipbreaking industry where workers are largely unprotected and the removed asbestos is dumped in the open (NGO Shipbreaking Platform, 2013).

\section{International Ban Asbestos Secretariat (IBAS)}

International Ban Asbestos Secretariat (IBAS) is one of a number of anti-asbestos lobbying civil society organisations. Established in 2000, its mandate is to provide "a conduit for the exchange of information between groups and individuals working to achieve a global asbestos ban and seeking to alleviate the damage caused by widespread asbestos use" (IBAS, 2014). Disturbed by the lack of accountability and responsibility by former asbestos industry players in developed countries, combined with the current exploitation of communities in the 
developing world, IBAS provides a platform to counter the asbestos industry's control of the information stream (IBAS, 2014). In order to highlight the social injustices surrounding both former and current industry activities, IBAS organises conferences, links to websites and information and material from a range of interested parties including health, legal, regulatory, environmental and occupational groups.

\section{CORPORATE GOVERNANCE AND RISK}

At the same time as the Earth Summit, the Cadbury Committee (1992) released its ground-breaking report on the financial aspects of corporate governance. This report focussed on governance arrangements to mitigate corporate risks and to minimise corporate failure (Cadbury, 1992). Since the exploitation of asbestos was and largely remains conducted in the realm of commercial enterprise, corporate management of the financial risks associated with the industry have become problematic.

The interface of corporate risk and governance regimes has led to a distinct bifurcation of responses to asbestos. In developed countries the industry players have either left or changed focus with a concomitant legacy issue of corporate responsibility for the health and environmental effects. In more advanced legal jurisdictions where the mining and use of asbestos has been banned, it has become a source of future financial risk in the guise of 'long-tail liabilities' (Moerman and van der Laan, 2012). Estimates of claims and the future costs for asbestos compensation have grown ${ }^{6}$ considerably in Australia, the US and the UK since the 1990s. Long-tail claims have increased for various reasons, including the awareness of legal rights and remedies and the manifestation of loss and injury from formerly 'acceptable' practices (Holyoak and Chambers 2008).

Therefore, we see the corporate risk arising from the long-tail liability pushing the boundaries of corporate governance and responsibility. Most often, this is expressed through the use of flexible corporate structures

\section{Eternit}

Ironically, the businessman credited with single-handedly developing a new environmental paradigm based on "ecoefficiency" (Schmidheiny 1992) also amassed a personal fortune from the

European asbestos conglomerate, Eternit (Berman 2012). Eternit left an environmental and health legacy throughout Europe, and in particular devastation in Casale Italy. The asbestos empire he headed resulted in a conviction for "gross negligence" in the highlypublicised Turin trial and sentenced to 18 years jail for failing to protect workers and consumers against the toxic effects of asbestos (Meni 2012). Schmidheiny has been quoted as saying, "I promise you, I will never go to an Italian prison" (in Bank, 2002), and continues to exploit legal avenues to ensure that does not happen. Clearly, Schmidheiny's 'polluter pays' principle does not apply personally 
to quarantine risk and isolate asbestos liabilities in a trust or special purpose entity. In the US, the asbestos industry has relied on 'unfavourable' accounting treatments to trigger an entitlement under bankruptcy provisions. The most notable example of this was the Manville Corporation equity bankruptcy in the early 1980s - a strategy subsequently pursued by numerous US-based asbestos companies ${ }^{7}$ (see Delaney, 1992). Consequently, in the US, the "Manville Provisions' (s524(g)) were introduced in 1994 to facilitate the reorganisation of companies with large asbestos liabilities (White, 2002). In other jurisdictions where bankruptcy regimes may not be so favourable, jettisoning or attempting to off-load subsidiaries with asbestos liabilities (e.g. James Hardie Industries in Australia - see Moerman and van der Laan, 2014 forthcoming) or allowing the entity to be taken over in a less hostile legal environment (e.g. Turner \& Newall $(T \& N)$ in the UK was acquired by Federal Mogul in the US, see Moerman and van der Laan 2013) or sell tainted assets (e.g. Eternit in Brazil, see Berman, 2012) have seen large corporate entities successfully socialise the risk associated with the exploitation of asbestos (Moerman and van der Laan 2012).

On the other hand, in countries where legal regimes are not as sophisticated and enforcement is weak, the advantages of exploiting asbestos at national level still dominate. Any consideration of the short and long term consequences of this toxic industry are often subsumed by economic imperatives, despite the reinforcement of the principles at Rio+20 United Nations Conference on Sustainable Development 2012.

We urge countries and other stakeholders to take all possible measures to prevent the unsound management of hazardous wastes and their illegal dumping, particularly in countries where the capacity to deal with these wastes is limited, in a manner consistent with countries' obligations under relevant international instruments (United Nations 2012, 39)

Reflecting on the statistics in Table 1, it is evident that the production and consumption of asbestos continues unabated. The only notable exception is the cessation of asbestos mining in Canada as a result of the lack of government support for the corporate interests in the industry (Kazan-Allen, 2013a).

However, while most developed nations ban asbestos, significant health risks remain with the abundance of ACM in the environment. Despite national efforts to ensure safe-handling and removal, a third and fourth wave of victims will continue well into the $21^{\text {st }}$ century. Combined with the realisation that the industry in less developed countries mirrors the landscape of global asbestos over three decades ago, the toxic effects will no doubt stretch even further into the future.

\section{CONCLUDING COMMENTS}

The toxic chemical, asbestos, provides a salient example of the ever-widening gap between the developed and the less developed world. Consistent with the Earth Summit and Agenda 21 Principles are the attempts at a coordinated strategic approach to eliminating asbestos and mitigating current and future risks. The ratification of legal instruments such as the Rotterdam and Basel Conventions; the implementation of ILO Conventions into national regulations and laws; and concerted efforts at education and fiscal mechanisms to reduce the use of asbestos are all examples of a holistic approach. However, the twin aspirations of a high quality environment and a healthy economy for all have clearly not been achieved as 
indicated by the continued production and consumption of asbestos in jurisdictions with weak national regulatory regimes and limited economic capacity to adapt.

Agenda 21 Principles in relation to toxic products and hazardous wastes see limited, if any, progress over the last 21 years. In the developing world, the statistics speak for themselves the amount of asbestos in use today will be the legacy of the $21^{\text {st }}$ century whether through current manufacturing, industrial and mining processes or the effects of ACM in the environment. Corporations and other industry participants play a major role in responses to the risks from a toxic chemical and have implications for corporate governance in a new era of sustainable development as articulated in the Rio+20 Future We Want - twenty years on from the original Rio declaration.

We commend existing [public-private partnerships] and call for continued, new and innovative public-private partnerships among industry, governments, academia and other non-governmental stakeholders aiming to enhance capacity and technology for environmentally sound chemicals and waste management, including for waste prevention (United Nations, 2012, para 217)

These future directions include the dispersion of knowledge about the hazards of asbestos, the availability of substitute materials in production combined with the provision of technology and skills to produce non-asbestos materials for use in developing countries. In the meantime, short term measures need to ensure that the supranational regulatory instruments are adopted and enforced in national regimes through compliance in both the public and private sector to achieve the aim of reducing hazardous wastes and toxic products. These objectives will contribute to the Rio sustainability aspirations of a "high quality environment and a healthy economy for all people of the world" (UNESCO, n.d. p.1) 


\section{References}

Bank, D. (2002) 'Moral Fiber: Billionaire Activist On Environment Faces His Own Past - An 'Eco-Efficiency' Advocate, Swiss Magnate Confronts Questions on Asbestos - Mr.

Schmidheiny's Conscience', Wall Street Journal, December, 9.

Basel Convention (2014) Basel Convention,

http://www.basel.int/TheConvention/Overview/tabid/1271/Default.aspx, Accessed

July 22, 2014.

Berman, D. (2012)'Asbestos Magnate or Environmental Guru: The Trials of Stefan

Schmidheiny', Chapter 3 in Allen, D. and Kazan-Allen, L. (eds) Eternit and the Great Asbestos Trial, IBAS, London

Bright, J. and Salamie, D. (2007) 'CSR Limited', International Directory of Company Histories, Volume 85, St James Press, New York.

BWI (2014) BWI and IndustriAll conference on asbestos in Vienna issue Vienna Declaration http://www.bwint.org/default.asp?index $=5516 \&$ Language $=E N$, Accessed July 22, 2014.

Cadbury, A. (1992) Report of the Committee on the Financial Aspects of Corporate Governance, Gee, London, http://www.ecgi.org/codes/documents/cadbury.pdf, Accessed June 30, 2014.

CSR Limited (2014) Annual Report 2014, www.csr.com.au. Accessed June 16, 2014.

Delaney, K. (1992) Strategic Bankruptcy, University of California Press, Oxford.

Donlevy, N. and Perkins, J. (2005) 'Asbestos Implications of the NSW Government's Legislative Reforms', paper presented at the Institute of Actuaries of Australia XVth General Insurance Seminar, 16-19 October.

Durkin, T. (1990) How Do Risks Become Social? ABF Working Paper \#900. University of Chicago, American Bar Foundation.

http://www.ilo.org/safework/info/standards-and-instruments/WCMS_108556/lang-en/index.htm. Accessed July 23, 2014.

IARC Monograph Working Group (2009), 'A Review of Human Carcinogens - Part C: Metals, Arsenic, Dusts and Fibres', The Lancet, 10 (May): 453-4.

ILO (2006) Resolution concerning asbestos, June 1. http://www.ilo.org/safework/info/standards-and-instruments/WCMS 108556/lang-en/index.htm. Accessed $22^{\text {nd }}$ July 2014.

International Ban Asbestos Secretariat (IBAS) (2014) About IBAS, http://www.ibasecretariat.org/about.htm, Accessed July 23, 2014.

Kazan-Allen, L. (2013a) Asbestos Profile - Canada, www.ibasecretariate.org Accessed September 15, 2014.

Kazan-Allen, L. (2013b) Rotterdam Convention 2013 - an activist diary, www.ibasecretariate.org Accessed July 22, 2014.

Lee, J. (2005), 'Asbestos Litigation - the Third Wave', paper presented at the Medico-Legal Society of NSW Inc. Scientific Meeting, March, www.medicolegal.org.au/index2.php?option=com_content, Accessed October 16, 2010.

Lowe, J. (Chair) (2004) UK Asbestos - The Definitive Guide, http://www.actuaries.org.uk/sites/all/files/documents/pdf/Lowe_0.pdf. Accessed June $10,2010$.

Magaisa, A. (2001) Suing Multinational Corporate Groups for Torts in the Wake of the Lubbe Case, Law, Social Justice and Development Journal, Iss. 2. pp. 1-8.

McCulloch, J. (2003) 'Asbestos Mining in Southern Africa', 1893-2002, International Journal of Occupational Health, 9: 230-235. 
Meni, F. (2012) 'The Eternit Factory at Casale Monferrato', Chapter 5 in Allen, D. and Kazan-Allen, L. (eds) Eternit and the Great Asbestos Trial, IBAS, London.

Moerman, L. and van der Laan, S. (2011) 'Accounting for long-tail asbestos liabilities: Metaphor and meaning', Accounting Forum, Vol.35:1, pp. 11-18.

Moerman, L. and van der Laan, S. (2012) 'Risky Business: Socialising Asbestos Risk and the Hybridisation of Accounting', Critical Perspectives on Accounting, Vol. 23, 2, pp. $107-116$.

Moerman, L. and van der Laan, S. (2013) Accounting and Long-tail Liabilities: the case of asbestos, March, Research Report 130, ACCA UK, London.

Moerman, L. and van der Laan, S. (2014 forthcoming) 'Silencing the Noise: Asbestos liabilities, accounting and strategic bankruptcy', Critical Perspectives on Accounting.

NGO Shipbreaking Platform (2013) Civil society organisations in Asia call for a global ban on asbestos, highlight dangers in shipbreaking, http://www.shipbreakingplatform.org/platform-news-civil-society-organisations-inasia-call-for-a-global-ban-on-asbestos-dangers-in-shipbreaking-highlighted/ Accessed July 23, 2014.

Orszag, J. (2003), 'The Impact of Asbestos Liabilities on Workers in Bankrupt Firms', presentation at Understanding Asbestos Litigation: The Genesis, Scope and Impact for the US Chamber of Commerce, 23 January.

Rotterdam Convention (2014) Rotterdam Convention, http://www.pic.int/TheConvention/Overview/tabid/1044/language/enUS/Default.aspx, Accessed July 22, 2014

Salvatore, L., Santoni, A. and Michaels, D. (2003), Asbestos: The Current Situation in Europe (Tillinghast-Towers Perrin) London. http://www.actuaries.org/ASTIN/Colloquia/Berlin/Salvatori_Santoni_Michaels.pdf accessed 10 June 2010.

Schmidheiny, S. (1992) Changing Course: A Global Business Perspective on Development and the Environment, The MIT Press, Cambridge.

Spender, P. (2003) 'Blue Asbestos and Golden Eggs: Evaluating Bankruptcy and Class Actions as Just Responses to Mass Tort Liability', Sydney Law Review, 25: 223-254.

Stockholm Convention (2014) Stockholm Convention, http://chm.pops.int/TheConvention/Overview/tabid/3351/Default.aspx. Accessed 22 July 2014.

Union Aid Abroad (APHEDA) (2013) Building asbestos awareness in Laos, Report to Donors 2012-2013 www.apheda.org.au, Accessed July 22, 2014.

United Nations Conference on Environment and Development (UNCED) (1992) The Rio Declaration on Environment and Development (1992),

http://www.un.org/documents/ga/conf151/aconf15126-1annex1.htm. Accessed May 19 May 2014.

United Nations Educational, Scientific and Cultural Organization (UNESCO) (n.d.) The Rio Declaration on Environment and Development 1992: The Earth Summit and Agenda 21, www.unesco.org/education/nfsunesco/pdf/RIO_E.PDF. Accessed $14^{\text {th }}$ April 2014.

United Nations Sustainable Development (1992) Agenda 21, http://sustainabledevelopment.un.org/content/documents/Agenda21.pdf. Accessed May 19, 2014.

United Nations (2012) The Future We Want, http://www.un.org/en/sustainablefuture/. Accessed September 22, 2014.

Virta, R. (2006) Worldwide asbestos supply and consumption trends from 1900 through 2003, US Geological Survey Circular 1298, www.usgs.gov. Accessed June 10, 2010. 
Virta, R. (2013) The 2012 Minerals Yearbook: Asbestos [Advanced Release], http://minerals.usgs.gov/minerals/pubs/commodity/asbestos/. Accessed April 14, 2014

Virta, R. (2014) Asbestos, http://minerals.usgs.gov/minerals/pubs/commodity/asbestos/ Accessed April 14, 2014.

White, M., 'Why the Asbestos Genie Won't Stay in the Bankruptcy Bottle', presented at the Bankruptcy and Corporate Reorganization Conference, University of Cincinnati College of Law, March 2002.

World Health Organization (WHO) (2010) Elimination of Asbestos-related Diseases, Fact Sheet 343, July, available at: http://www.who.int/mediacentre/factsheets/fs343/en/. Accessed June 16, 2014.

World Health Organization (WHO) (2014) International Programme on Industrial Safety, http://www.who.int/ipcs/assessment/public health/asbestos/en/ . Accessed June 16, 2014.

\footnotetext{
${ }^{1}$ The United Nations Conference on Environment and Development (UNCED) held in Rio De Janeiro in 1992 is also known colloquially as the Rio Summit, Rio Conference and the Earth Summit.

${ }^{2}$ Canada was a leading producer of asbestos, however, asbestos production has decreased significantly following the Quebec government's refusal to fund infrastructure at the Jeffrey Mine (IBAS, 2014)

${ }^{3}$ According to WHO (2014) asbestos can also cause cancer of the larynx and ovary.

${ }^{4}$ The Stockholm Convention on Persistent Organic Pollutions is also promulgated by UNEP in 2001 and entered into force in $\mathbf{2 0 0 4}$ is one of a suite of overlapping conventions, however does not refer directly to asbestos.

${ }^{5}$ The disability-adjusted life year (DALY) is a measure of overall disease burden, expressed as the number of years lost due to ill-health, disability or early death.

${ }^{6}$ Growth in the cost can be attributed to many factors including increases in claims, settlement amount, legal and administrative costs. In Australia, the US and the UK growth in claim numbers has far exceeded original projections (Donlevy and Perkins 2005).

7 In 2003, Orszag claimed that 61 US companies had filed for bankruptcy protection under Chapter 11 of the US Bankruptcy Code solely as a result of asbestos litigation (Orszag 2003).
}

Lee Moerman is an Associate Professor in the accounting discipline at the University of Wollongong in Australia. Lee's research interests include social accounting and accountability.

Sandra van der Laan is an Associate Professor in the accounting discipline at The University of Sydney Business School. Sandra's research interests include the social effects of corporate structures. 